\title{
man
}

\section{強度・延性に優れた電析バルクナノ結晶材料を 実現可能にする成長モード制御}

\author{
松 井 功*
}

\section{1. 高強度と高延性を両立する電析バルクナノ結晶材料}

近年，ますます深刻になる資源問題の解決や今後の社会発 展を実現していくために，各種製品のエネルギー効率の向上 が必要であり，これを可能にするための金属系部材に抢ける

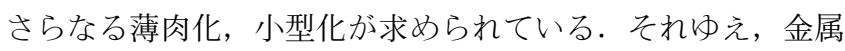
材料の強度, 勒性, 疲労特性などの向上を目的とした研究が 盛んに行われている。これを実現する一つの方策が，金属材 料抢ける結晶粒の微細化である. 1989年, Gleiterによって ナノ結晶メタル (100 nm 以下の結晶粒で構成された多結晶 金属材料)の特異な性質として, 極めて高い強度と延性の向 上の両立が予見された ${ }^{(1)}$. ナノ結晶メタルへの次世代型構造 材料としての期待から, 現在に至るまで, 数多くのナノ結晶 メタルの作製とその機械的性質の評価が行われてき た(2)-(4)、過去に報告されたナノ結晶メタルは, 硬度試験や 引張試験において従来の粗粒材料に比して高い強度を示す一 方で，その延性は極めて乏しく，我々の期待を裏切るもので あった ${ }^{(3)}$. 典型的な例として, 図 1 に電析ナノ結晶 $\mathrm{Ni}-\mathrm{W}$ 合金の引張強度と引張伸びの関係を示す，過去に報告された 電析ナノ結晶 $\mathrm{Ni}-\mathrm{W}$ 合金 ${ }^{(5)-(10)}$ の引張伸びは， $2 \%$ 程度と乏 しく, 延性の付与ならびに向上が課題となっていた. ナノ結 晶メタルの低延性の要因として, Ma は, 試料形状の課題点 として試料が非常に薄膜 $(<50 \mathrm{~m})$ であり欠陥や表面の凹凸 に非常に敏感であることを挙げ, バルク材の必要性を示唆し た(11)。また，Kochらは，作製方法の課題点として，焼結を 用いる Two-step プロセスに起因した試料の低密度や欠陥の 存在を挙げ，焼結を必要としない One-step プロセスを推奖
している(3).

このような背景を受け, 近年, 著者らのグループでは, バ ルク材の作製が可能であり且つ One-step プロセスである電 析プロセスに着目し, 電析バルクナノ結晶メタルの作製抒よ びその引張特性評価を行ってきた ${ }^{(12)-(16)}$. 先述の $\mathrm{Ni}-\mathrm{W}$ 合 金電析は, 一般的に電流効率が $30 \%-40 \%$ 程度と低く ${ }^{(17)}$, 電 析中に副反応として水素ガスが多量に発生する. これらの水 素ガスの巻き込み, 脱離が繰り返されることで, 電析皮膜中 に欠宿や高い内部応力が生じることが知られて抢り, 電流効 率の改善が求められていた ${ }^{(18)}$.また, 電流効率の向上によ り, バルク材の効率的な作製が期待できる. そこで, 著者ら

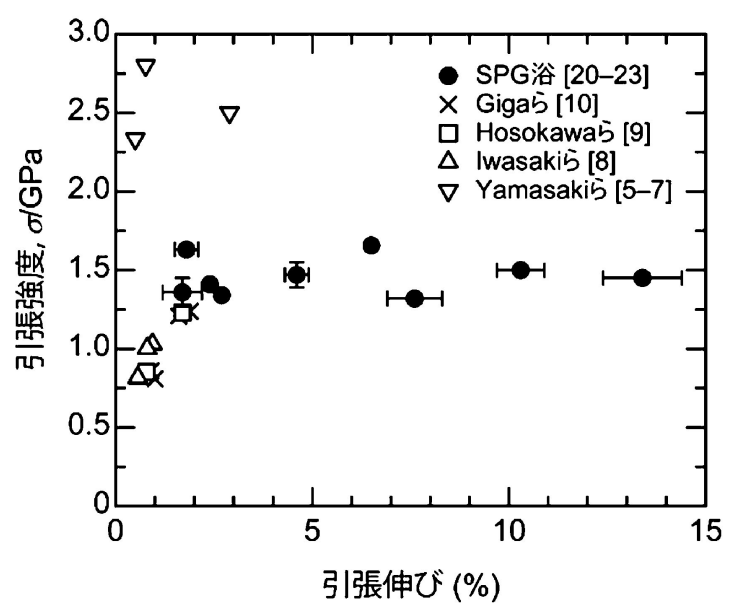

図 1 過去に報告された電析ナノ結晶 $\mathrm{Ni}-\mathrm{W}$ 合金 ${ }^{(5)-(10)}$ および開発した電析バルクナノ結晶 $\mathrm{Ni}-\mathrm{W}$ 合 金 ${ }^{(20)-(23)}$ の引張強度と引張伸びの関係.

* 国立研究開発法人産業技術総合研究所 構造材料研究部門 ; 研究員 ( Controlling the Growth Mode for Producing Electrodeposited Bulk Nanocrystalline Metals and Alloys with Good Combination of Strength and Ductility; Isao Matsui (Structural Materials Research Institute, National Institute of Advanced Industrial Science and Technology (AIST), Nagoya)

Keywords: nanocrystalline metals, electrodeposition, $N i-W$ alloys, tensile properties, orientation index, growth mode 2016年 1 月 18 日受理[doi:10.2320/materia.55.166] 


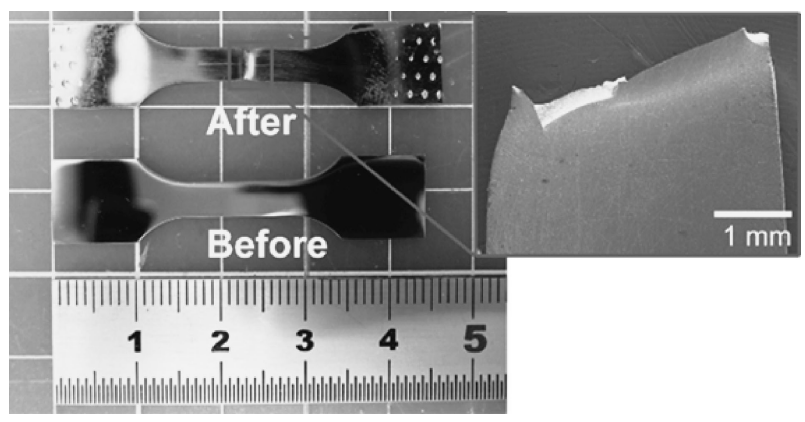

図 2 高強度 ·高延性電析バルクナノ結晶 $\mathrm{Ni}-\mathrm{W}$ 合金 の引張試験片の外観写真 ${ }^{21)}$ ならびに走査型電子 顕微鏡像 ${ }^{(27)}$.

は，まず，高電流効率を示す新規な $\mathrm{Ni}-\mathrm{W}$ 合金電析浴の開 発を行った. $\mathrm{Ni}-\mathrm{W}$ 合金電析浴の低電流効率は, 錯化剂とし て用いられるクエン酸に起因していることがすでに明らかに されているため(17), クエン酸に代わる錯化剂を検討し ${ }^{(19)}$, さらに内部応力低減に効果のある添加剤の影響について調査 を行った ${ }^{(20)}$. その結果, 内部応力減少剤としてサッカリン ナトリウム，錯化剤としてプロピオン酸とグルコン酸ナトリ ウムを用いた SPG 浴により $90 \%$ 程度の非常に高い電流効率 を実現した ${ }^{(20)}$ 。また，SPG 浴から得られる電析バルクナノ 結晶 $\mathrm{Ni}-\mathrm{W}$ 合金は，タングステン含有量 1.0 at \%程度を示す とともに 20-30 nm 程度の結晶粒を有していた。さらに $\mathrm{SPG}$ 浴から作製された電析バルクナノ結晶 $\mathrm{Ni}-\mathrm{W}$ 合金は, 引張強度 $1.45 \mathrm{GPa}$, 引張伸び $13.4 \%$ という従来の電析ナノ 結晶 $\mathrm{Ni}-\mathrm{W}$ 合金の高強度に加えて高延性を発現した ${ }^{(21)}$. 図 2 に高強度と高延性の両立した電析バルクナノ結晶 $\mathrm{Ni}-\mathrm{W}$ 合金の引張試験片の外観写真と走査型電子顕微鏡像を示す. 図 2 から，電析バルクナノ結晶 $\mathrm{Ni}-\mathrm{W}$ 合金が優れた塑性変 形能を有していることが確認できる．著者らは電析バルクナ ノ結晶メタルの延性改善に向け, 電析浴の電流効率改善とい う観点から研究を進めてきた。しかしながら, 図 1 に示す ように $90 \%$ 程度の高電流効率を示す SPG 浴から作製した電 析 $\mathrm{Ni}-\mathrm{W}$ 合金試料(20)-(23)に抢いて，すべての試料が優れた 引張伸びを発現しておらず，電流効率改善と延性発現が一対 一で対応していないことが示された。

\section{2. 延性と成長モードの関係}

先述したように電析浴の電流効率改善はバルクナノ結晶メ タルの作製において重要であるが，延性発現の十分条件では なかった。一方で， $\mathrm{Ni}-\mathrm{W}$ 合金電析浴に対する添加剤の影響 について検討を行った際の結果を比較すると，(111)面に配 向した試料は引張試験に抢いて弾性領域内で破断し，(200) 面に配向した試料は塑性変形能を示しており，延性に対して 配向性が何らかの形で関与していることが示唆された ${ }^{(20)}$. そこで, 電析バルクナノ結晶 $\mathrm{Ni}-\mathrm{W}$ 合金に拈ける (111), (200)，および (220) 面の配向度 $N_{h k l}$ を以下の式 (1)を用い て算出し延性との相関性を検討した。

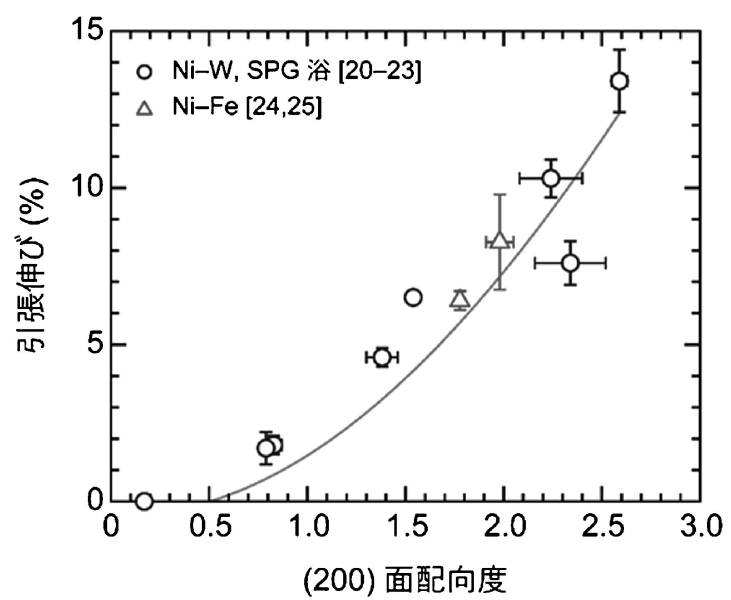

図 3 過去に報告された電析バルクナノ結晶 $\mathrm{Ni}$ 合 金(24)(25) および SPG 浴から作製した電析バルク ナノ結晶 $\mathrm{Ni}-\mathrm{W}$ 合金 ${ }^{(20)-(23)}$ の引張伸びと (200)面 配向度の関係.

$$
N_{h k l}=\frac{I_{h k l}}{I_{111}+I_{200}+I_{220}} / \frac{I_{h k l}^{\prime}}{I_{111}^{\prime}+I_{200}^{\prime}+I_{220}^{\prime}}
$$

ここで， $I_{h k l}$ は本研究で得られた電析 $\mathrm{Ni}-\mathrm{W}$ 合金における回 折ピーク強度であり， $I_{h k l}^{\prime}$ は ICDD のデータベースから得ら れる標準ニッケルにおける回折ピーク強度を示す. 図 3 に電 析バルクナノ結晶 $\mathrm{Ni}-\mathrm{W}$ 合金の引張伸びと算出した (200)面 配向度の関係を示す。電析合金に扔ける(200)面配向度の増 加に伴い引張伸びが増加する傾向が確認できる，また，過去 に報告された電析バルクナノ結晶 $\mathrm{Ni}-\mathrm{Fe}$ 合金 ${ }^{(24)(25)}$ について も，同様の傾向が図 3 から確認することができる．この結 果は, 電析バルクナノ結晶メタルの延性を(200)面配向度に て整理可能であることを示している.

過去に Amblard らは電析被膜の配向性が，電析時に招け る被膜の成長モードによって決定されることを報告してい る ${ }^{(26)}$. 具体的には, (111) 面配向，(200)面配向，および (220)面配向は，それぞれ inhibited lateral growth, free lateral growth，および inhibited out growth によって形成さ れる. また, inhibited lateral growth, inhibited out growth に拉いて, 水素ガス, 水素イオンがそれぞれ電析反応を阻害 するインヒビターとして振る舞うとされている．図４に各成 長モードの模式図 ${ }^{(27)}$ を示す，inhibited out growth では，成 長面に水素が吸着することで被膜の成長を阻害する，そのた め, 電析皮膜は水素原子を巻き込みながら成長するため, 結 果として水素含有量の多い試料となると考えられる. また， 吸着水素の存在により皮膜の成長が不均一に行われると同時 に, 電流密度分布も不均一なものとなる. 高電流密度部と低 電流密度部が存在するため, 溶質原子や不純物元素が局所的 に存在しひずみをもたらす。その結果として，試料全体に大 きな内部応力が生じマクロな欠陥が生じる．実際に，(220) 面に配向した電析 $\mathrm{Ni}-\mathrm{W}$ 合金試料は， 0.44 at \% と高い水素 含有量を示すとともに表面に多数の亀裂が存在していた．続 いて, inhibited lateral growthでは，電析皮膜の成長を水素 


\section{Inhibited out growth}

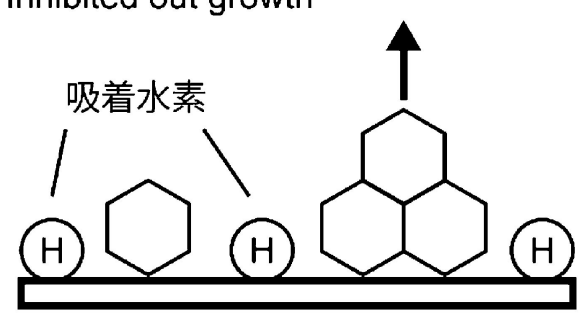

Inhibited lateral growth

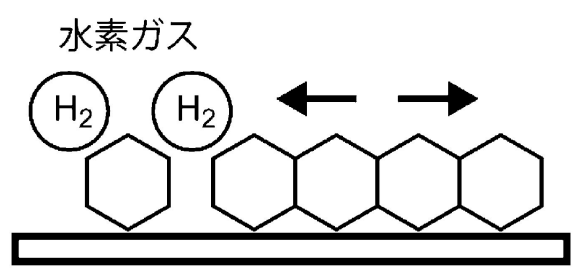

Free lateral growth

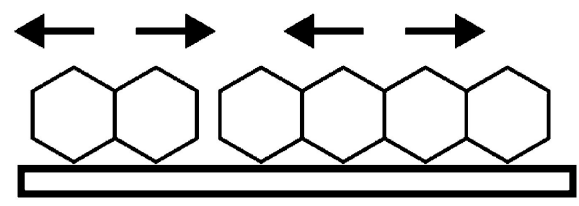

図 4 電析時の成長モードの模式図 ${ }^{(27)}$.

ガスが阻害する，そのため，電析皮膜は水素ガスを巻き込み ながら成長する. 同時に, 水素ガスは電析皮膜から脱離して いくため, 水素ガスが存在していた場所にナノボイドが形成 する。そのゆえ, inhibited lateral growthより得られる試料 には多数のナノボイド・ナノクラックが存在して抢り, 引張 試験などにおいて, これらの微小な欠陥から亀裂が進展する ため早期の破断が起きるものと考元られる．実際に，(111) 面に配向した電析 $\mathrm{Ni}-\mathrm{W}$ 合金試料は $0.04 \mathrm{at} \%$ と (220) 面に配 向した試料に比べて低い水素含有量である一方で, 引張伸び は $2 \%$ 程度と乏しい値であった．吸着水素や水素ガスなどの インヒビターが存在する成長モードに対して, free lateral growthに打いては，インヒビターが存在しないため，イン ヒビターに起因した欠陥を形成することなく皮膜が成長する ものと考元られる. 実際に, (200) 面に配向した電析 $\mathrm{Ni}-\mathrm{W}$ 合金試料の水素含有量は 0.02 at $\%$ と他の試料に比べて低 く, また，10\%を超える引張伸びを有していた，以上の結 果から, 電析バルクナノ結晶メタルの延性発現は, 電析時の 成長モードに強く影響を受けて抢り，その成長が free lateral growthにより行われることで欠陥フリーな高密度な電析 試料が作製され高延性の発現がもたらされることが明らかと なった ${ }^{(27)}$.

\section{3. 高延性を得るための基本指針}

電析バルクナノ結晶 $\mathrm{Ni}-\mathrm{W}$ 合金の延性と配向性の関係に

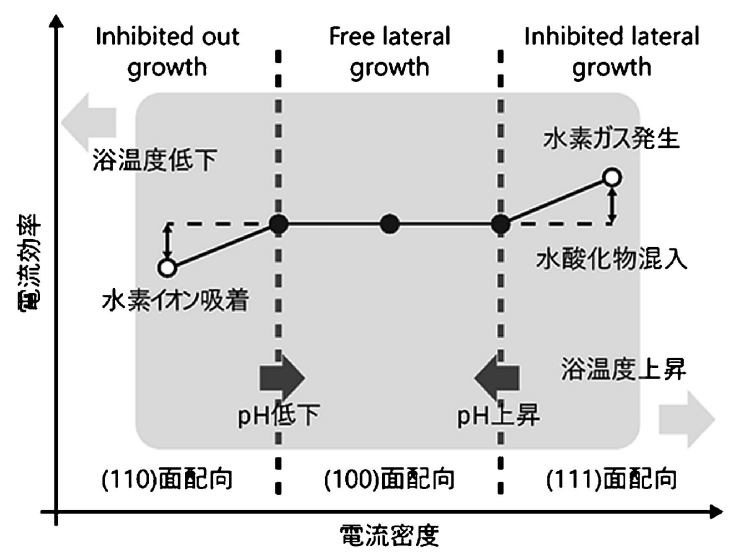

図 5 高強度・高延性バルクナノ結晶メタル創出のた めの電析条件設定ガイドライン ${ }^{(27)}$.

関する議論から，電析バルクナノ結晶メタルの延性発現に抢 いて電析時の成長モードの制御が必要であることが示され た。そこで, 著者のこれまでの電析実験の結果に基づいた電 析条件と成長モード(配向性)の相関図を図 5 に示す，本相関 図では, 電析条件として電流密度, 浴温度, $\mathrm{pH}$ を, 電析後 に得られるパラメーターとして電流効率㧍よび配向性 (成長 モード)を挙げている.

電流密度は，低・中・高の 3 つの領域に分類される，印 加する電流密度が低い場合には, 所望する電析反応が十分に 行わ扎ず吸着水素によって電析反応が阻害される. また, こ の場合には若干の電流効率の低下が確認できる。 また, 電流 密度が高い場合には, 水素ガス発生 $\left(2 \mathrm{H}_{2} \mathrm{O} \longrightarrow \mathrm{H}_{2} \uparrow+\right.$ $\left.2 O H^{-}\right)$を引き起こし, 水素ガスによる被膜の成長阻害なら びに水酸化物の生成抢よび被膜への混入が起きる。これらの 生成物の巻き込反によって若干の電流効率の増加が確認でき る.このため, 電流効率は, 電流密度に対して階段状に増加 するものと考えられる．このような増加傾向は, 過去の報 告(28)(29)に扔いて子確認できる.

電流密度を 3 つの領域に分類したが，これらの 3 つの領 域はそれぞれ浴温度に大きく影響を受ける。浴温度の上昇し た場合には, 電流密度の領域はそれぞれ高電流密度側にシフ トし, 浴温度の減少は, 低電流密度側へのシフトをもたら す。それゆえ, 浴温度の上昇によりバルクナノ結晶メタル作 製の高速化が期待されるが，同時に，水溶液の蒸発が活発に なり電析浴の維持が困難になる，さらに，活発な水溶液の蒸 発により多量の水蒸気が発生することで, 水素ガスによる電 析反応の阻害と同様の環境が構築される危険性がある.

最後に, $\mathrm{pH}$ につて影響について考察を行う。 $\mathrm{pH}$ を下 げていくと溶液中の水素イオン濃度が増加する。これによ り, 水素イオンが多量に存在することで, 水素イオンによる 電析反応の阻害つまり inhibited out growth を誘発すること となる，一方で， $\mathrm{pH}$ を上げていくと溶液中の水酸化イオン 濃度が増加する.これにより, 水酸化物の形成が促進される こととなる.これにより, 被膜中への水酸化物の混入が生じ るとともに, inhibited lateral growth を助長することとなる. 


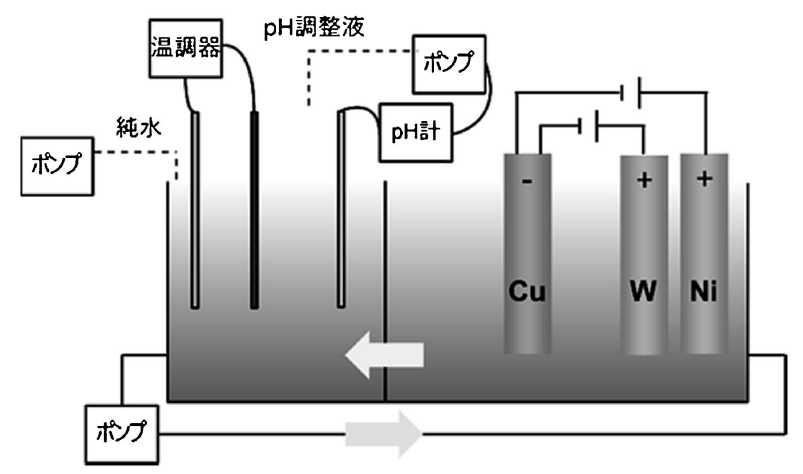

図 6 電析装置の概略図.

\section{4. 電析装置と今後の課題}

電析における各パラメーターの成長モードに対する影響に ついて，定性的ではあるがまとめを行うとともに相関図(図 5)を示した。電析実験は，ビーカー，マグネットスターラ 一, 直流電源抢よび試薬などを準備することで簡単に実験を 開始することが可能である. 一方で, 高強度と高延性の両立 に向けて, 各研究グループに扔いて独自の電析装置が開発さ れている(7)(30)(31)。また，著者が使用している電析システム は図 6 の概略図に示すとおりである。このように各研究グル 一プに打いて異なる電析装置が用いられている. 通常, 電析 時には基板近傍で所望する電析反応を過不足なく得るために 金属イオンの供給を目的とした浴液の攪拌が行われている. 浴液の流れ方や速度などは，浴槽の形状，用いるポンプ，お よび各種機器の配置などにより変化するものであり, 各電析 装置において “固有の攪汼” が存在しており，この攪汼を文 献から再現することは困難な状態にある。それゆえ，文献を 参考に電析実験を行った場合に扔いても所望する結果が得ら れない場合が多々起きてしまう。そのため，現状において は, 電析バルクナノ結晶メタルに扔いて高強度と高延性を得 るために，図 5 に示した相関図に基づきながら，実際の実 験に扔いて浴槽内をライトで照らしながら基板近傍で気泡が 吸着しているかどうかなど電析挙動を逐次確認しながら，各 電析システムに拈ける電析条件の最適值の抽出を行う必要が ある．さらなる電析バルクナノ結晶合金作製実験の再現性向 上には各装置に抢ける “固有の攪拌”の定量化抢よび相関図 （図 5)への組反込久が重要であると考元，現在，浴流の制御 ならびに影響調査に取り組んでいる。

\section{5. おわりに}

本稿では, 電析を用いた高強度・高延性を有するバルクナ ノ結晶合金の作製について紹介を行った，電析時における成 長モードの制御は, 電析バルクナノ結晶合金が高延性を発現 するために必須である，成長モードと配向性の関係が明らか にされている面心立法構造を有した系では，本稿で紹介した 電析条件と成長モードの関係 (図 5)を参照することで, 高延
性を得るための電析条件抽出の簡便化が期待できる. 実際 に, 著者らのグループでは, $\mathrm{Ni}-\mathrm{W}$ 合金のみならず, 高強度 と高延性を両立した電析バルクナノ結晶 $\mathrm{Ni}^{(13)} ， \mathrm{Fe}-\mathrm{Ni}$ 合 金(15)(16)の作製を可能にしている，さらに，非水溶液の有機 溶媒浴から得られる電析 $\mathrm{A} 1$ への塑性変形能の付与にも成功 している ${ }^{(32)}$. 今後は, 本知見をべースに, 高強度・高延性 に加えて使用試薬の規制フリー化 ${ }^{(23)}$ ，粒界脆化元素による 延性低下の抑制，耐熱性の向上を重点的に推し進め，電析バ ルクナノ結晶合金の産業界進出への道を拓くことを目指して いきたい。

本研究の遂行にあたり, 大阪府立大学東健司教授, 瀧川順 庸准教授，上杉徳照講師には貴重なご指導およびご助言を頂 いた．同時に，東研究室に在籍した学生抢よび院生の協力は 必要不可欠なものであった. トロント大学 U. Erb 教授には 留学の機会を頂くとともに公私にわたりご助言を頂いた。 ま た，著者の現所属である産業技術総合研究所構造材料研究部 門の諸先輩方からもご助力を頂いた。本研究の一部は, JSPS 基盤研究 (C) (22560726), 同 (25390031), 研究活動久 タート支援 (26886014)などの支援を受けて遂行した。末筆 ながら本稿を執筆する機会を与えて下さった関係各位に深く 御礼申し上げます。

\section{文献}

(1) H. Gleiter: Prog. Mater Sci., 33(1989), 223-315.

( 2 ) M. A. Meyers, A. Mishra and D. J. Benson: Prog. Mater Sci., 51 (2006), 427-556.

( 3 ) C. C. Koch, K. M. Youssef, R. O. Scattergood and K. L. Murty: Adv. Eng. Mater., 7 (2005), 787-794.

( 4 ) M. Dao, L. Lu, R. Asaro, J. Dehosson and E. Ma: Acta Mater., 55 (2007), 4041-4065.

( 5 ) T. Yamasaki: Scr. Mater., 44(2001), 1497-1502.

( 6 ) K. Fujita, T. Suidu and T. Yamasaki: J. Jpn. Inst. Met., 75 (2011), 348-354.

( 7 ) S. Nakayama, H. Adachi and T. Yamasaki: J. Alloys Compd., 643, Supplement 1(2015), S22-S26.

( 8 ) H. Iwasaki, K. Higashi and T. G. Nieh: Scr. Mater., 50(2004), 395-399.

( 9 ) H. Hosokawa, H. Matsumoto, M. Hakamada and M. Mabuchi: J. Mater. Sci., 41(2006), 8372-8376.

(10) A. Giga, Y. Kimoto, Y. Takigawa and K. Higashi: Scr. Mater., $\mathbf{5 5}(2006), 143-146$.

(11) E. Ma: Scr. Mater., 49(2003), 663-668.

(12) I. Matsui, Y. Takigawa, T. Uesugi and K. Higashi: Mater. Trans., 52(2011), 142-146.

(13) I. Matsui, Y. Takigawa, T. Uesugi and K. Higashi: Mater. Lett., 65(2011), 2351-2353.

(14) I. Matsui, S. Ono, Y. Takigawa, T. Uesugi and K. Higashi: Mater. Sci. Eng. A, 550(2012), 363-366.

(15) I. Matsui, T. Kawakatsu, Y. Takigawa, T. Uesugi and K. Higashi: Mater. Lett., 116(2014), 71-74.

(16) I. Matsui, H. Mori, T. Kawakatsu, Y. Takigawa, T. Uesugi and K. Higashi: Mater. Sci. Eng. A, 607 (2014), 505-510.

(17) I. Mizushima, P. T. Tang, H. N. Hansen and M. A. J. Somers: Electrochim. Acta, 51(2005), 888-896.

(18) I. Mizushima, P. T. Tang, H. N. Hansen and M. A. J. Somers: Electrochim. Acta, 51(2006), 6128-6134.

(19) I. Matsui, Y. Takigawa, T. Uesugi and K. Higashi: Micro- 
electron. Eng., 91 (2012), 98-101.

(20) I. Matsui, Y. Takigawa, T. Uesugi and K. Higashi: Mater. Lett., 99 (2013), 65-67.

(21) I. Matsui, Y. Takigawa, T. Uesugi and K. Higashi: Mater. Sci. Eng. A, 578(2013), 318-322.

(22) I. Matsui, Y. Takigawa and K. Higashi: Adv. Mater. Res., 922 (2014), 497-502.

(23) I. Matsui, N. Omura, M. Li, Y. Murakami and S. Tada: J. Japan Inst. Met. Mater., 80 (2016), 217-223.

(24) H. Wei, G. D. Hibbard, G. Palumbo and U. Erb: Scr. Mater., 57 (2007), 996-999.

(25) G. J. Fan, L. F. Fu, H. Choo, P. K. Liaw and N. D. Browning: Acta Mater., 54 (2006), 4781-4792.

(26) J. Amblard, I. Epelboin, M. Froment and G. Maurin: J. Appl. Electrochem., 9(1979), 233-242.

(27) I. Matsui, Y. Takigawa, D. Yokoe, T. Kato, T. Uesugi and K. Higashi: Mater. Trans., 55(2014), 1859-1866.

(28) Y. Wu, D. Chang, D. Kim and S.-C. Kwon: Surf. Coat. Technol., 173(2003), 259-264.
(29) J.-X. Kang, W.-Z. Zhao and G.-F. Zhang: Surf. Coat. Technol., 203(2009), 1815-1818.

30) Y. Kimoto, S. Wakayama, A. Fujii, Y. Takigawa and K. Higashi: Mater. Trans., 48(2007), 1483-1491.

(31) I. Brooks: Ph. D. thesis, University of Toronto, Toronto, Ont., Canada, 2012.

(32) I. Matsui, Y. Hanaoka, S. Ono, Y. Takigawa, T. Uesugi and K. Higashi: Mater. Lett., 109(2013), 229-232.

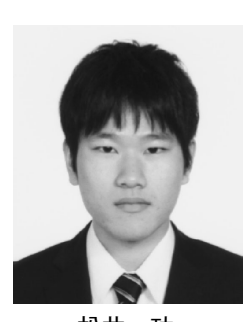

松井 功

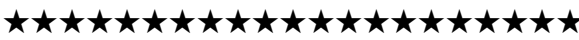
2011年-2014年 日本学術振興会特別研究員 (DC1) 2012年 4 月-8 月 トロント大学(留学)

2014年 3 月 大阪府立大学大学院工学研究科物質 化学系専攻博士後期課程修了

2014年 4 月- 現職 専門分野 : ナノ結晶材料

○電析によるバルクナノ結晶合金の創製扔よび機械的

\section{特性向上に資する研究に従事.}

